\title{
Recent applications of Italian anti-seismic devices
}

\author{
M. G. Castellano \& S. Infanti \\ Research \& Development Department, FIP Industriale spa, Italy
}

\begin{abstract}
In the last three decades anti-seismic devices, in particular those implementing the passive control of structural response through seismic isolation and energy dissipation, have undergone great development, finding many applications in both new and existing structures. Since the 1970s Italy has been giving a strong contribution to said development, so that it soon became the country with the largest number of seismically isolated bridges (over 150 bridges and over 100 $\mathrm{km}$ by 1992). The application of passive control techniques in Italian buildings was slow at the beginning; however in last five years, due to the change of seismic code in 2003, many buildings benefited from different types of antiseismic devices. New buildings, in particular strategic buildings such as hospitals, are more and more often protected by seismic isolation, which guarantees their full functionality even immediately after a strong earthquake. Seismic isolation has also been implemented to retrofit existing buildings. More often existing RC framed buildings, in particular schools, have been retrofitted through dissipative bracings, exploiting their capability to reduce the ductility request of structural members and thus the damage. Since the late 1980s, Italian anti-seismic devices have been applied in other countries too - ranging from Mediterranean seismic-prone countries to the USA, from Bangladesh to South America. Some of the outstanding projects in which Italian anti-seismic devices have been used are the Rion-Antirion Bridge in Greece, the Taipei 101 skyscraper in Taipei, the Stonecutters Bridge in Hong Kong, the St. Francis Shangri-La Towers in Manila, etc. Some recent applications of Italian antiseismic devices are described in this paper.
\end{abstract}

Keywords: seismic isolation, energy dissipation, passive control, viscous dampers, steel hysteretic dampers, elastomeric isolators, shock transmission units, seismic retrofit, earthquake engineering. 


\section{Introduction}

Anti-seismic devices are defined by the relevant European standard [1] as devices that are provided in structures with the aim of modifying their response to the seismic action. Such modification can be done by isolating the structure, by dissipating energy or by creating permanent or temporary restraints via rigid connections. The first two ways, i.e. seismic isolation and energy dissipation, often combined, have come of age in the last 30 years [2-4] as an alternative to conventional seismic design methods accepting even serious damages to the structure provided it does not collapse. Conversely, seismic isolation and energy dissipation avoid any damage to the structure; furthermore, seismic isolation also protects the content of buildings, thanks to the strong reduction of acceleration even at the highest floors.

Figure 1 shows the anti-seismic devices manufactured in Italy, as classified according to the European Standard. Information on some of the said antiseismic devices is given by Castellano and Infanti [5].

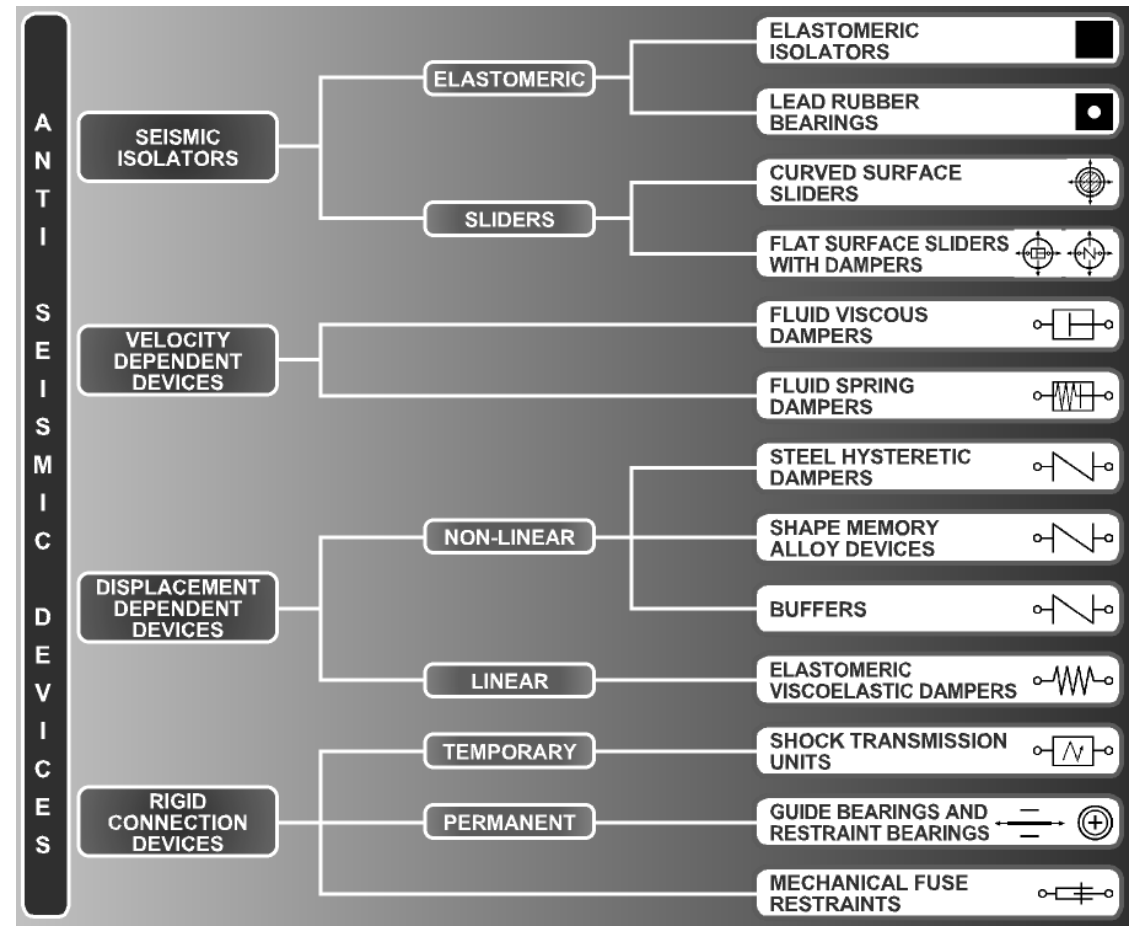

Figure 1: $\quad$ List of anti-seismic devices manufactured in Italy.

The first application of seismic isolation in Italy was in the 1970s in the Somplago Viaduct on the Udine-Tarvisio motorway; this was also the first isolated bridge in Europe. Thanks to the good response of this viaduct to the 1976 Friuli earthquake, whose epicenter was only few kilometers away, in the 
following 10 years new seismic devices were developed and applied in hundreds of bridges, so that Italy soon became the country with the largest number of seismically isolated bridges (over 150 bridges and over $100 \mathrm{~km}$ by 1992) [2].

The applications of seismic isolation/energy dissipation to buildings in Italy started only a few years after those in bridges, at the beginning of the 1980s, but they increased very slowly, mainly due to lack of a specific code and very long design approval procedures. However, after the new Italian seismic code, including specific chapters about seismic isolation of buildings and bridges, was published in 2003 and updated in 2005 [6], the use of anti-seismic devices in buildings became more common.

Thanks to the continue research and development since the Seventies, Italian anti-seismic devices have found worldwide applications since the late eighties.

This paper summarizes the applications of anti-seismic devices manufactured by FIP Industriale in the last five years, i.e. from 2003 to 2008, focusing on seismic isolators and energy dissipation devices, and paying more attention to building applications than bridge applications.

\section{Applications in bridges}

More than 5,000 isolators and dampers manufactured by FIP Industriale were applied in bridges and viaducts in Italy and other countries in last five years. Amongst said applications, some are of particular importance either for the importance of the structure or for the number of devices installed.

For example, a major application in Europe is the Rion-Antirion cable-stayed bridge in Greece, where the largest fluid viscous dampers ever built were applied to control the transverse movement of the main bridge deck during strong earthquakes [7]; together with the 20 dampers for the main bridge, further 168 dampers were installed in the approach viaducts.

The Sheikh Zayed Bridge in Abu Dhabi, representing a landmark structure in the United Arab Emirates and a challenge to structural engineers, is protected by a combination of fuse restraints, viscous dampers and elastic restrainers [8].

In the Stonecutters Bridge in Hong Kong $8000 \mathrm{kN}$ shock transmission units were used to cope with strong wind and earthquakes [9].

The construction of the Caracas-Tuy Medio Railway line in Venezuela was recently completed: more than 1500 isolators - flat surface sliders with steel hysteretic dampers (Figure 2) - were used on the viaducts of said $40 \mathrm{~km}$ line [10, 11]. Now the new Railway line Puerto Cabello-La Encrucijada, $120 \mathrm{~km}$ long, is under construction with the same type of isolation system.

The use of elastomeric isolators in bridge increased in last years: more than 2300 high damping elastomeric isolators were installed in last five years, most of them in Italy and in Algeria.

Amongst retrofit applications, worth of note are those to the ISAP Railway Bridge in Athens, Greece [12], to the Carboj, San Vincenzo I and San Vincenzo II Viaducts on the main road No. SS 115 in Sicily, Italy [13], to the 20 viaducts on the S.S. 647 highway, in Southern Italy $[13,14]$, and to some bridges in Korea. 


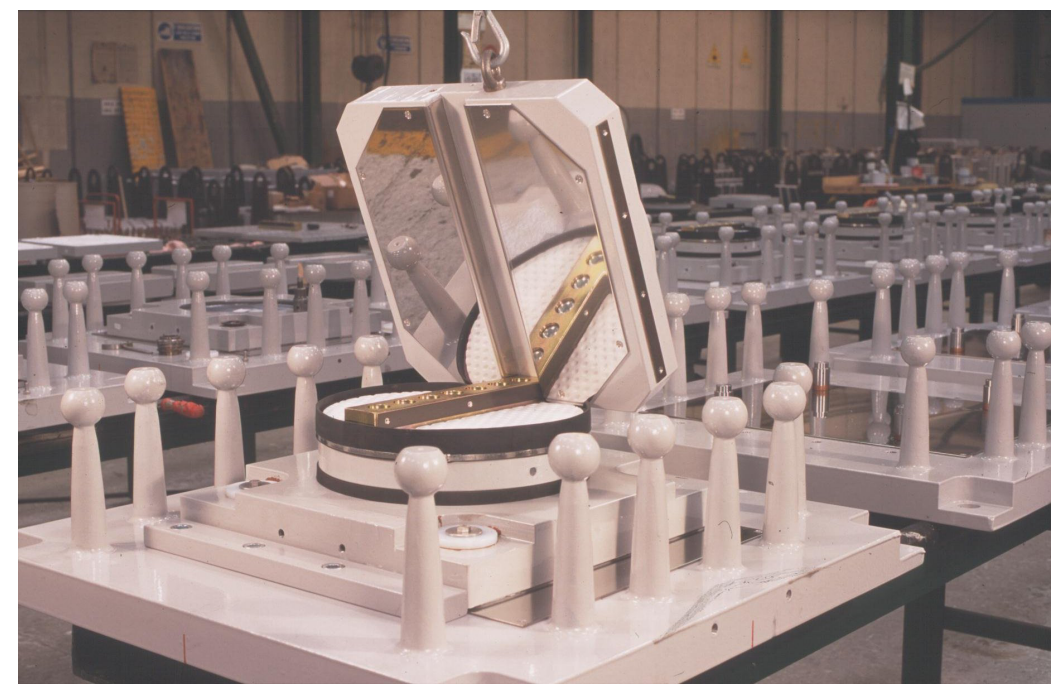

Figure 2: A flat surface slider with steel hysteretic dampers for the CaracasTuy Medio railway in Venezuela under assembling.

\section{Applications in buildings in Italy}

In last five years the applications of seismic isolation in Italian buildings are significantly increased.

About 1000 elastomeric isolators have been applied in about 30 buildings. Most of said elastomeric isolators are made by high damping rubber, but more than $10 \%$ are Lead Rubber Bearings. In most applications elastomeric isolators are combined with flat surface sliders; such solution allows to reach high fundamental period even in buildings with few stories, i.e. with low mass, and also allows a reduction in cost of the isolation system.

It is worth noting the isolation of a new big hospital, the "Ospedale del Mare" in Naples [15], where 327 elastomeric isolators were used (Figure 3).

Most of isolated buildings are new, but in some case seismic isolation was used for retrofit of existing buildings. For example, two residential buildings in Solarino, one of which was subjected to snap-back tests [16], and more recently the "Quasimodo" school in Riposto, both in Sicily.

A very challenging application was the retrofit of the "Madonna delle Lacrime" sanctuary in Syracuse, a structure with an imposing dome, stock-conic, circular base shaped roof, with a $71.40 \mathrm{~m}$ base diameter. The new seismic regulations [6], which has fundamentally changed seismic design actions, required seismic roof isolation, that was done by introducing new seismic isolators between the dome's base ring and the pillars supporting it, replacing the 22 existing bearings. This was the first application in a building of flat surface sliders with steel hysteretic dampers (Figure 4), an isolator type till now often used in bridges and viaducts in Italy and abroad. FIP Industriale both supplied 
and installed the isolators; the latter required raising the dome (weighing about 22,000 tons) using 114 jacks worked simultaneously, replacing the bearings with new isolators and lowering the dome unloading all the jacks simultaneously [17].

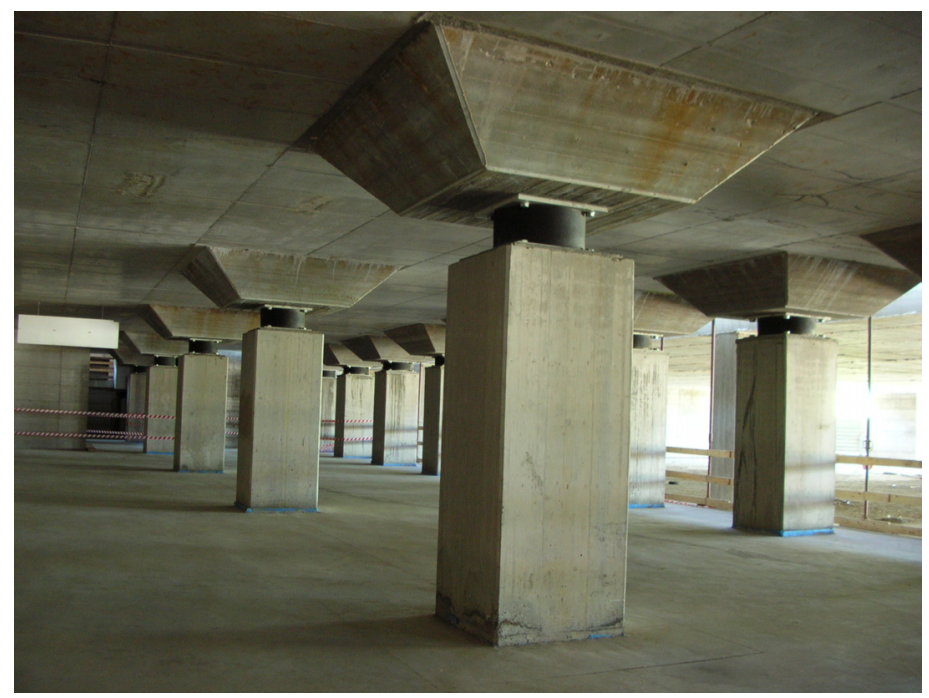

Figure 3: Elastomeric isolators installed in the Ospedale del Mare, Naples, Italy.

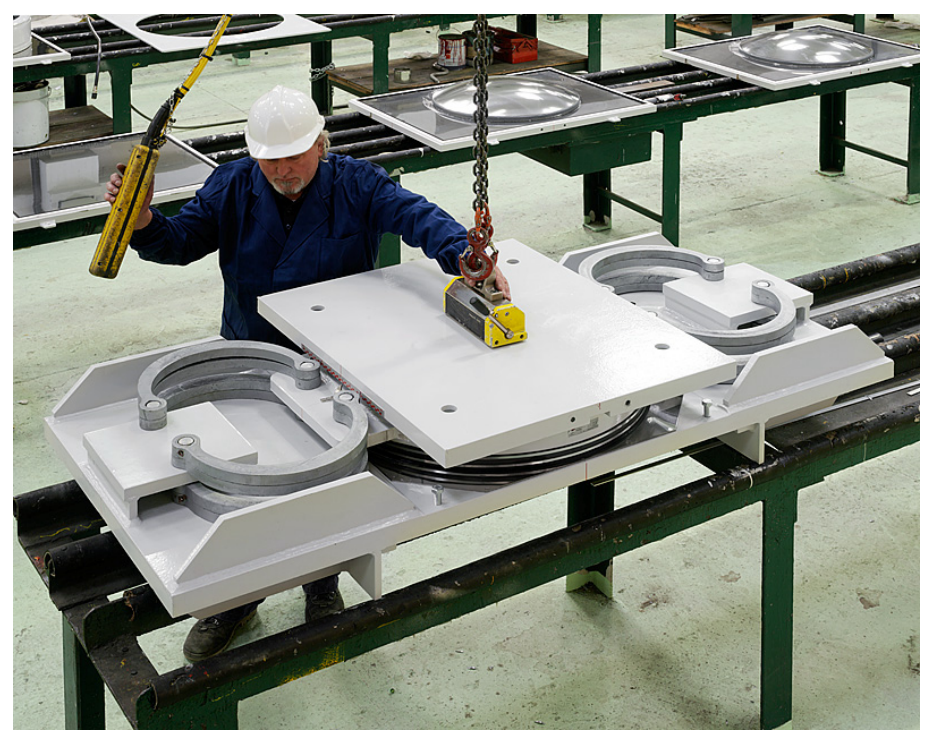

Figure 4: A flat surface slider with steel hysteretic dampers for the "Madonna delle Lacrime" sanctuary in Syracuse, Italy. 
In many cases, when seismic isolation is not possible or too expensive, seismic retrofit of RC framed buildings, in particular schools, has been carried out by introducing dissipative bracings. For example, Figure 5 shows bucklingrestrained axial dampers installed in the School "Cappuccini" in Ramacca. Other examples are the High Schools "Perticari" in Senigallia [18] and "Porro" in Pinerolo.

Dissipative bracings with buckling-restrained axial dampers have also been used to increase ductility and hyper-staticity of a new pre-cast building [19]. It represents the first application of buckling restrained braces in Italy and Europe.

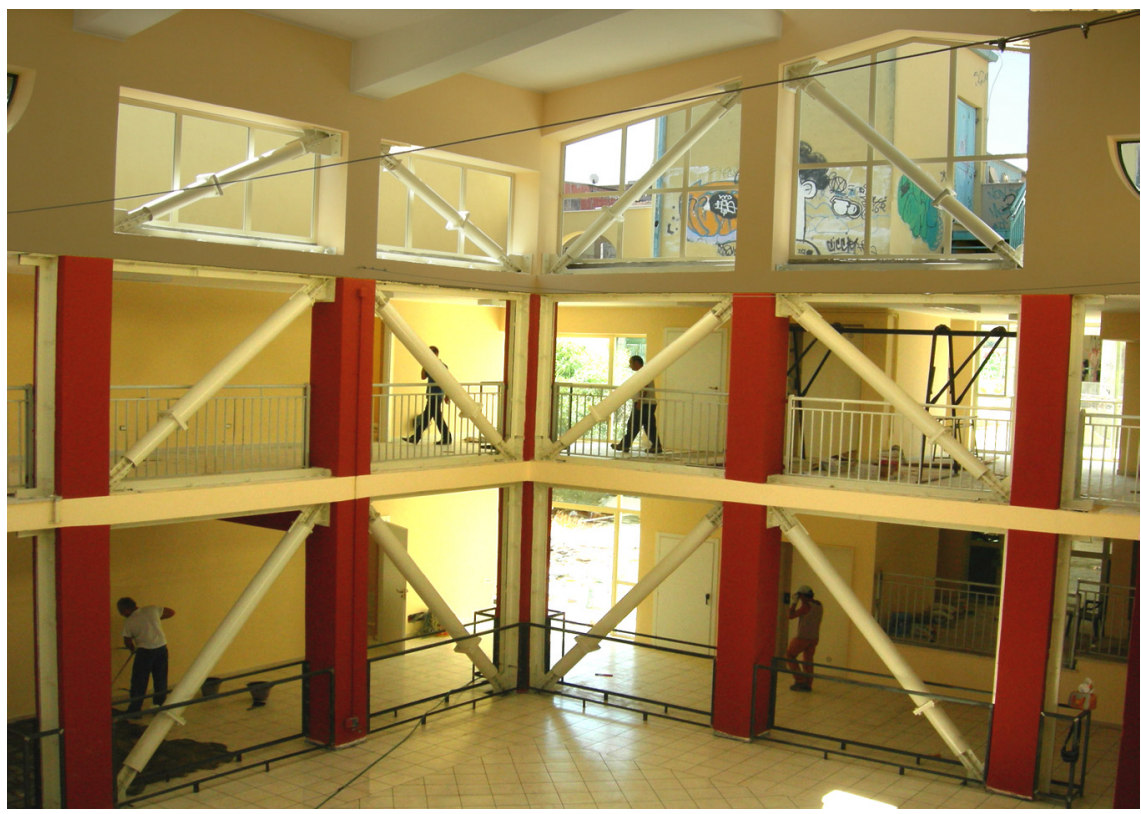

Figure 5: Buckling-restrained axial dampers installed in the School "Cappuccini" in Ramacca, Italy (courtesy of Prof. Fabio Neri).

\section{Applications in buildings outside Italy}

During the last five years FIP Industriale provided elastomeric isolators for the Hospital "Da Luz" in Lisbon, the first isolated building in Portugal [20, 21], for the 27 storey Sea Plaza Hotel, part of the development of the Black Sea city of Sochi (Russia) in view of the 2014 Olympic Winter Games, and for the retrofit of a fire station in Basilea (Switzerland).

The Taipei 101 skyscraper in Taipei (Taiwan) with its $508 \mathrm{~m}$ has been the world's tallest building since 2004. It is equipped with a tuned mass damper (TMD) that can considerably reduce oscillation due to strong winds or earthquakes [22]. Said TMD is made of a $660 \mathrm{t}$ mass, suspended on long cables to create a 5 storey long pendulum, and by 8 viscous dampers linking the mass to 
the underlying storey, built by FIP Industriale (Figure 6). The specificness of these dampers is their ability to react through different constitutive laws to movements caused by earthquake or wind that differ in speed [23]. The TMD has already been put into operation by earthquakes in March 2005 and May 2008 (Sichuan Earthquake) and by many strong typhoons (especially throughout an active typhoon season in mid to late 2005). During some of these events, building performance data were obtained via the on-site monitoring system, and the TMD was observed to behave as the design intended.

More recently viscous dampers with similar behaviour have been installed in the two St. Francis Shangri-La Towers in Manila, Philippines, each rising to 213 m. In this case, 32 viscous dampers (Figure 7) are installed into the towers structure according to an Arup newly developed and patented configuration [24, 25]. A wide laboratory testing campaign was carried out, aimed at verifying the behaviour of fluid viscous dampers during both wind storms and earthquake [23].

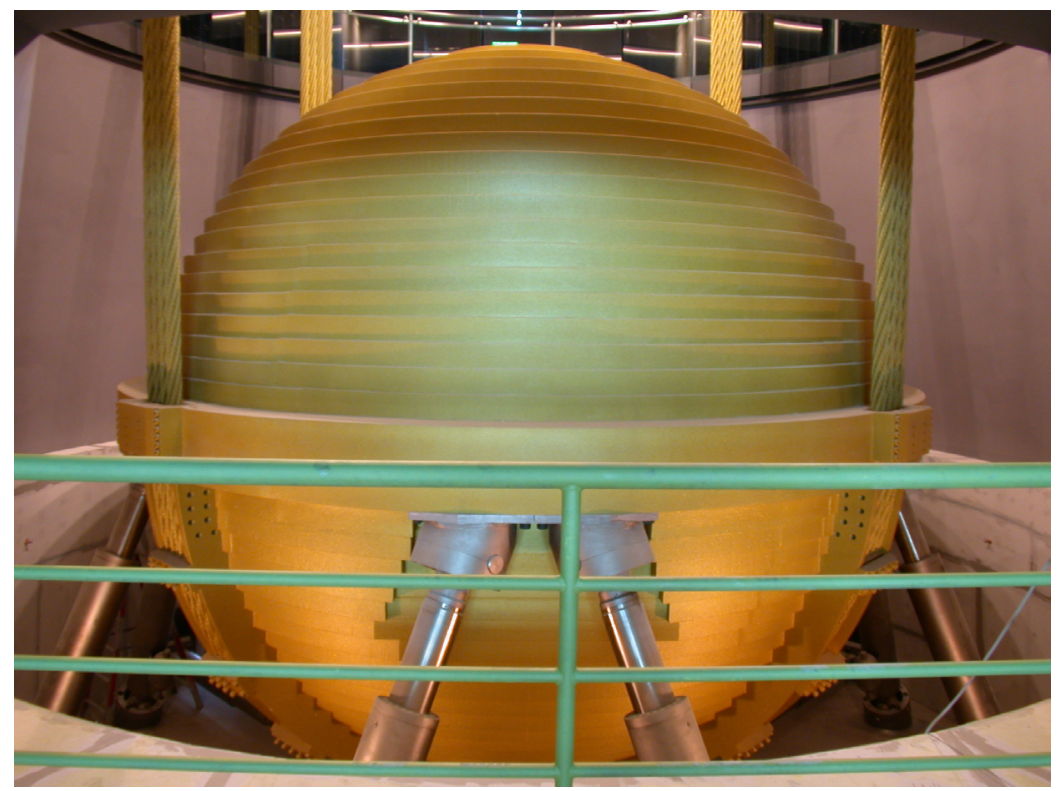

Figure 6: The TMD at the top of Taipei 101, in Taipei, Taiwan (courtesy of Motioneering).

\section{Conclusions}

The examples of recent applications of Italian anti-seismic devices given above show that the wide range of technologies available is suitable for seismic protection of many types of structures, differing in technical characteristics as well as in value. 
In Italy the number of the structures seismically protected through antiseismic devices is expected to increase during the next years, thanks to both the increasing interest of the engineering community towards this new approach and the new seismic code. The latter provides specific rules regarding the design of structures equipped with anti-seismic devices and the tests required to check the devices reliability.

The European standard on anti-seismic devices will help in guaranteeing high-grade products and a fair competition amongst different manufacturers. It will also support structural engineers in acquiring the deep knowledge essential to select the most effective solution for each structure.

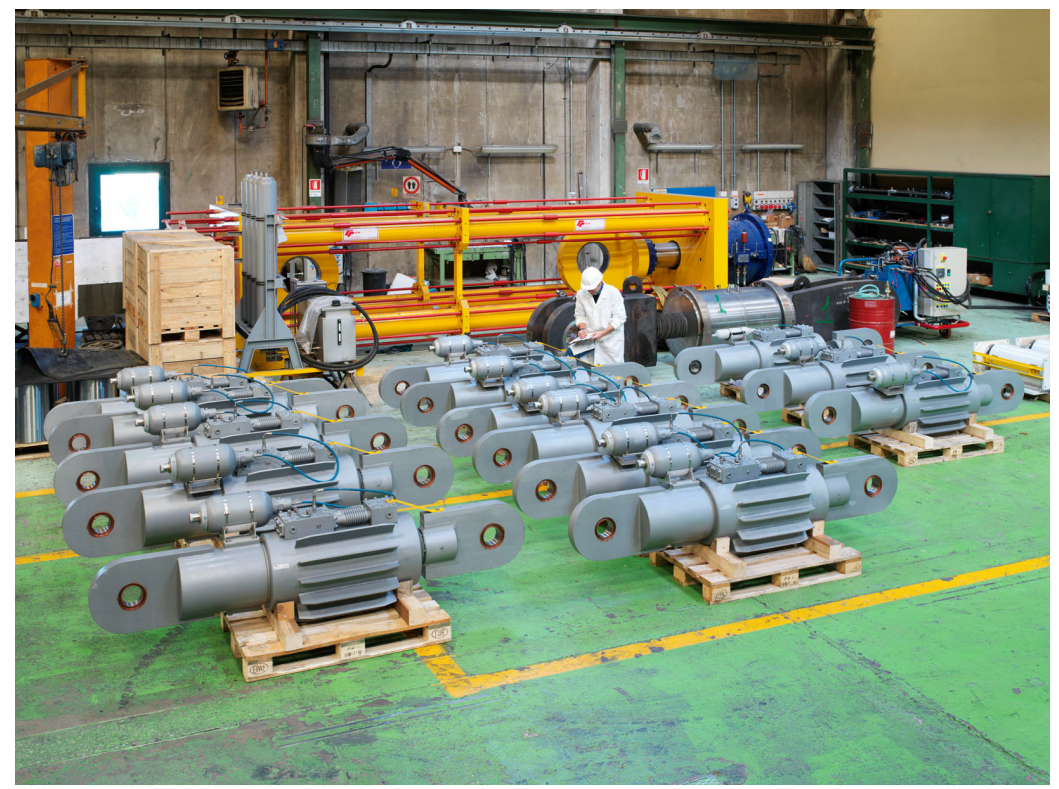

Figure 7: The fluid viscous dampers for the St. Francis Shangri-La Towers in Manila, Philippines.

\section{References}

[1] CEN/TC340. prEN 15129:2008 Anti-seismic devices. CEN: 2008.

[2] Skinner, R.I., Robinson, W.H. \& McVerry, G. H., An introduction to seismic isolation, Wiley: Chichester, 1993.

[3] Soong, T.T. \& Dargush, G.F., Passive energy dissipation systems in structural engineering, Wiley: Chichester, 1997.

[4] Buckle, I.G., Passive control of structures for seismic loads. Proc. of 12WCEE, Auckland, New Zealand, paper $\mathrm{n}^{\circ} 2825,2000$.

[5] Castellano, M.G., Infanti, S., Italian technologies for seismic isolation and energy dissipation, Proceedings of the International Symposium on Earthquake Engineering Commemorating Tenth Anniversary of the 1995 Kobe Earthquake (ISEE Kobe 2005), Kobe/Awaji, Japan, 2005. 
[6] OPCM 3431, Norme tecniche per il progetto, la valutazione e l'adeguamento sismico degli edifici, Testo integrato dell'Allegato 2 Edifici - all'Ordinanza 3274 come modificato dall'OPCM 3431 del 3/5/05, Italy, 2005 (Standard for design, evaluation and seismic retrofit of buildings, in Italian).

[7] Infanti, S., Papanikolas, P., Theodossopoulos, G., Rion-Antirion Bridge: Full-Scale Testing of Seismic Devices, Proceedings of fib Symposium Concrete Structures in Seismic Regions, Athens, Greece, 2003.

[8] Infanti, S., Castellano, M.G., Sheikh Zayed Bridge seismic protection system, Proceedings of 10th World Conference on Seismic Isolation, Energy Dissipation and active Vibrations Control of Structures, Istanbul, Turkey, 2007.

[9] Colato, G.P., Chiarotto R., Fetti, M., Infanti, S., Castellano, M.G., Stonecutters cable-stayed bridge: full-scale testing of dynamic control devices. Proc. of $14^{\text {th }}$ World Conference on Earthquake Engineering, Beijing, China, October 12-17, 2008.

[10] Pérez, R., Nieto, J., Solórzano, E., Baldo, P., Design philosophy of the Caracas-Tuy Medio Railway Viaducts in Venezuela. Proc. of Fifth World Congress on Joints, Bearings and Seismic Systems for Concrete Structures, Rome, October 2001.

[11] Pérez, R., Nieto, J., Solórzano, E., Baldo, P., Tomaselli, F., Design criteria of the seismic dissipation system for the viaducts of the Caracas-Tuy Medio Railroad in Venezuela. Proc. of Fifth World Congress on Joints, Bearings and Seismic Systems for Concrete Structures, Rome, October 2001.

[12] Infanti, S., Tsiknias, T., Castellano, M.G., Tomaselli, F., Viscous dampers: recent major applications in European bridges. Proceedings of Sixth World Congress on Joints, Bearings and Seismic Systems for Concrete Structure, Halifax, Canada, September 17-21, 2006.

[13] Castellano, M.G., Infanti, S., Colato, G.P., Battaini, M., The Italian experience in the retrofit of bridges through seismic isolation and energy dissipation. Proceedings of 10th World Conference on Seismic Isolation, Energy Dissipation and active Vibrations Control of Structures, Istanbul, Turkey, May 27-30, 2007.

[14] Infanti, S., Castellano, M.G., Colato, G.P., Chiarotto, R., Contin, A., Fluid viscous dampers and steel hysteretic dampers combined in the seismic retrofit of viaducts. Proceedings of Sixth World Congress on Joints, Bearings and Seismic Systems for Concrete Structure, Halifax, Canada, September 17-21, 2006.

[15] Di Sarno, L., De Risi, B., Mascolo, C., Application of base isolation to a large hospital building, Proceedings of First European Conference on Earthquake Engineering and Seismology (1st ECEES), Geneva, Switzerland, Paper No. 48., 2006.

[16] Oliveto, N.D., Scalia, G., Oliveto, G., Dynamic identification of structural systems with viscous and friction damping, Journal of Sound and Vibration, 318, pp. 911-926, 2008. 
[17] Serino, G., Spizzuoco, M., Marsico, M.R., The "Santuario della Madonna delle Lacrime" in Siracusa as recent application of structural isolation and health monitoring, Proc. of $2^{\text {nd }}$ International Conference on Experimental Vibration Analysis for Civil Engineering Structures (EVACES'07), Porto, Portugal, 2007.

[18] Antonucci, R., Cappanera, F., Balducci, F., Castellano, M.G., Adeguamento sismico del Liceo classico "Perticari" di Senigallia (AN), Atti del XII Convegno Nazionale ANIDIS L’Ingegneria sismica in Italia, Pisa, Italy, 2007 (in Italian).

[19] Antonucci, R., Balducci, F., Castellano, M.G., Donà, F., Pre-casted RC buildings with buckling restrained braces: the example of the new building of the faculty of engineering in Ancona, Proceedings of the Second International fib Congress, Napoli, Italy, paper No. 879, 2006.

[20] Guerreiro, L., Prazeres Ferreira, J., Colato, G.P., M.G., Baldo, P., Base isolation for seismic protection - The new hospital in Lisbon, Proceedings of IABSE Symposium on Structures and Extreme Events, Lisbon, Portugal, 2005.

[21] Prazeres Ferreira, J., Hospital da Luz - Um edifício com isolamento sísmico de base, Engenharia e vida, anno III, N. 25, 2006 (in Portuguese).

[22] Haskett, T., Breukelman, B., Robinson, J., Kottelenberg, J., Tuned Mass Dampers under Excessive Structural Excitation, Motioneering.

[23] Infanti, S., Robinson, J., Smith, R., Viscous dampers for high-rise buildings. Proc. of $14^{\text {th }}$ World Conference on Earthquake Engineering, Beijing, China,

[24] Smith, R., Willford, M., The damped outrigger concept for tall buildings. The Structural Design of Tall and Special Buildings, Vol. 16, pp. 501-517, 2007 (available for download from www.ctbuh.org).

[25] Smith, R., Willford, M., Performance based seismic and wind engineering for 60 storey tower. Proc. of $14^{\text {th }}$ World Conference on Earthquake Engineering, Beijing, China, October 12-17, 2008. 